\title{
Secular oxidation of Archean upper mantle caused by increasing crustal recycling
}

\section{Lei Gao}

China University of Geosciences, Beijing

\section{Shuwen Liu ( $\sim$ swliu@pku.edu.cn )}

Peking University https://orcid.org/0000-0002-3487-7498

\section{Peter Cawood}

Monash University https://orcid.org/0000-0003-1200-3826

\section{Jintuan Wang}

State Key Laboratory of Isotope Geochemistry, Guangzhou Institute of Geochemistry, CAS, Guangzhou 510640, PR China

\section{Guozheng Sun}

Peking University

\section{Yalu Hu}

Peking University

\section{Fangyang Hu}

Institute of Geology and Geophysics, Chinese Academy of Sciences, Beijing

\section{Article}

Keywords: archean mantle, lithology, crustal recycling

Posted Date: October 1st, 2021

DOI: https://doi.org/10.21203/rs.3.rs-948127/v1

License: (1) This work is licensed under a Creative Commons Attribution 4.0 International License.

Read Full License

Version of Record: A version of this preprint was published at Nature Communications on June 7th, 2022. See the published version at https://doi.org/10.1038/s41467-022-30886-4. 


\section{Secular oxidation of Archean upper mantle caused by} increasing crustal recycling

Lei Gao ${ }^{1,2}$, Shuwen Liu ${ }^{2 *}$, Peter A. Cawood ${ }^{3 *}$, Jintuan Wang ${ }^{4}$, Guozheng Sun ${ }^{2}$, Yalu $\mathrm{Hu}^{2}$, Fangyang $\mathrm{Hu}^{5}$

${ }^{1}$ Key Laboratory of Geological Processes and Mineral Resources, School of Earth Sciences and Resources, China University of Geosciences, Beijing 100083, PR China

${ }^{2}$ Key Laboratory of Orogenic Belts and Crustal Evolution, Ministry of Education, School of Earth and Space Sciences, Peking University, Beijing 100871, PR China

${ }^{3}$ School of Earth, Atmosphere and Environment, Monash University, Melbourne, VIC 3800, Australia

${ }^{4}$ State Key Laboratory of Isotope Geochemistry, Guangzhou Institute of Geochemistry, CAS, Guangzhou 510640, PR China

5 State Key Laboratory of Lithospheric Evolution, Institute of Geology and Geophysics, Chinese Academy of Sciences, Beijing 100029, PR China

\section{*corresponding authors}

Shuwen Liu (swliu@pku.edu.cn)

Peter A. Cawood (peter.cawood@monash.edu) 
The redox evolution of Archean mantle impacted Earth differentiation, mantle melting and the nature of chemical equilibrium between mantle, ocean and atmosphere of the early Earth. However, how and why it varies with time remain controversial. Archean mantle-derived volcanic rocks, especially basalts are ideal lithologies for reconstructing the mantle redox state. Here we show that the $\sim 3.8-2.5$ Ga basalts from fourteen cratons are subdivided geochemically into two groups, B-1, showing incompatible element depleted and modern mid-ocean ridge basalt-like features $\left((\mathrm{Nb} / \mathrm{La})_{\mathrm{PM}} \geq 0.75\right)$ and $\mathrm{B}-2\left((\mathrm{Nb} / \mathrm{La})_{\mathrm{PM}}<0.75\right)$, characterized by modern island arc basalt-like features. Our updated V-Ti redox proxy indicates the Archean upper mantle was more reducing than today, and that there was a significant redox heterogeneity between ambient and modified mantle presumably related to crustal recycling, perhaps via plate subduction, as shown by B-1 and B-2 magmas, respectively. The oxygen fugacity of modified mantle exhibits a $\sim 1.5-2.0 \log$ units increase over $\sim 3.8-2.5 \mathrm{Ga}$, whereas the ambient mantle becomes more and more heterogeneous with respect to redox, apart from a significant increase at $\sim 2.7 \mathrm{Ga}$. These findings are coincident with the increase in the proportions of crustal recycling-related lithologies with associated enrichment of associated incompatible elements (e.g., $\mathrm{Th} / \mathrm{Nb}$ ), indicating that increasing recycling played a crucial role on the secular oxidation of Archean upper mantle. 
The redox state of Archean upper mantle buffered atmospheric composition and influenced the early ocean-atmosphere system through the geochemical behaviour of volatile elements (e.g., S, C and N) ${ }^{1-3}$. Previous investigations have mainly focused on the behaviour of redox-sensitive elements (e.g., V) in komatiites, showing a significant increase in mantle oxygen fugacity $\left(f \mathrm{O}_{2} ;\right.$ relative to the fayalite-magnetite-quartz buffer $(\triangle \mathrm{FMQ})$ ) between $\sim 3.5 \mathrm{Ga}$ and $1.9 \mathrm{Ga}^{3,4}$. This change, however, might not reflect the nature of the upper mantle as komatiite magmas are generally thought to have originated from either the core-mantle or the upper-lower mantle boundaries ${ }^{5}$. Compared to komatiites, the widespread appearance of Archean basalts offer alternative insights into resolving these issues ${ }^{1,6,7}$. Most studies indicated that the mantle $\mathrm{fO}_{2}$ has been oxidized to present-day levels since $\sim 3.9 \mathrm{Ga}^{6}$, but others inferred a dominantly reducing upper mantle on the basis of the significantly lower $\mathrm{V} / \mathrm{Sc}$ ratios in Archean mid-ocean ridge basalt (MORB)-like samples relative to their modern counterparts ${ }^{1,7}$. The reason of these contrasting interpretations is attributed to the choices of different mantle melting reactions and partition coefficients $(\mathrm{Kds})$ in converting $\mathrm{V} / \mathrm{Sc}$ ratios to mantle $f \mathrm{O}_{2}{ }^{1,6,7}$. Our recent study found that the $\mathrm{Kds}$ of $\mathrm{V}, \mathrm{Sc}$ and $\mathrm{Ti}$ are influenced not only by melting temperature, pressure and $f \mathrm{O}_{2}$, but also by the mantle mineral compositions ${ }^{8}$. Thus, suitable Kds and melting reactions are critical for accurate $f \mathrm{O}_{2}$ estimation. Although the MORB-like basalts were increasingly used in mantle $f \mathrm{O}_{2}$ calculation, limited investigations on another group of Archean basalts with similar characteristics to modern island arc basalt (IAB) impeded a comprehensive understanding of the 
geodynamic interactions across the asthenosphere, lithosphere and atmosphere of the early Earth ${ }^{8-10}$.

We have assembled a global whole-rock geochemical database of Archean $(\sim 3.8-2.5 \mathrm{Ga})$ mantle-derived volcanic rocks $(\mathrm{N}=2997$; Details of data collection, filtration and statistics are listed in Methods) from fourteen cratons (Fig. 1; Supplementary Fig. 1). The basalts exhibit compositional diversity, which is divided into Basalt-1 (B-1) and Basalt-2 (B-2) groups with modern MORB- and IAB-like chemical features, respectively ${ }^{11,12}$. We applied an updated V-Ti redox proxy, which may be more sensitive to V-Sc systematics because of the more incompatible character of Ti during mantle melting ${ }^{8}$, to this database and found: (1) The mean Ti/V ratios of Archean basalts are significantly lower than those of modern counterparts; (2) When converting to $f \mathrm{O}_{2}$, the Archean upper mantle was more reducing than it is today; and (3) As indicated by B-1 and B-2 magmas, respectively, there is a marked difference in redox state between ambient and modified mantle that was presumably related to crustal recycling, via plate subduction; (4) The modified mantle beneath the most cratons has become progressively oxidized over $\sim 3.8-2.5 \mathrm{Ga}$. These changes are closely associated with the increase in the proportions of $\mathrm{B}-2$, high-Mg andesite (HMA) and andesite samples, and the degree of enrichment in incompatible elements that on the modern Earth are related to the recycling of crustal materials via subduction zones. This indicates that the secular oxidation of Archean mantle was related to the increased crust recycling into the mantle. 


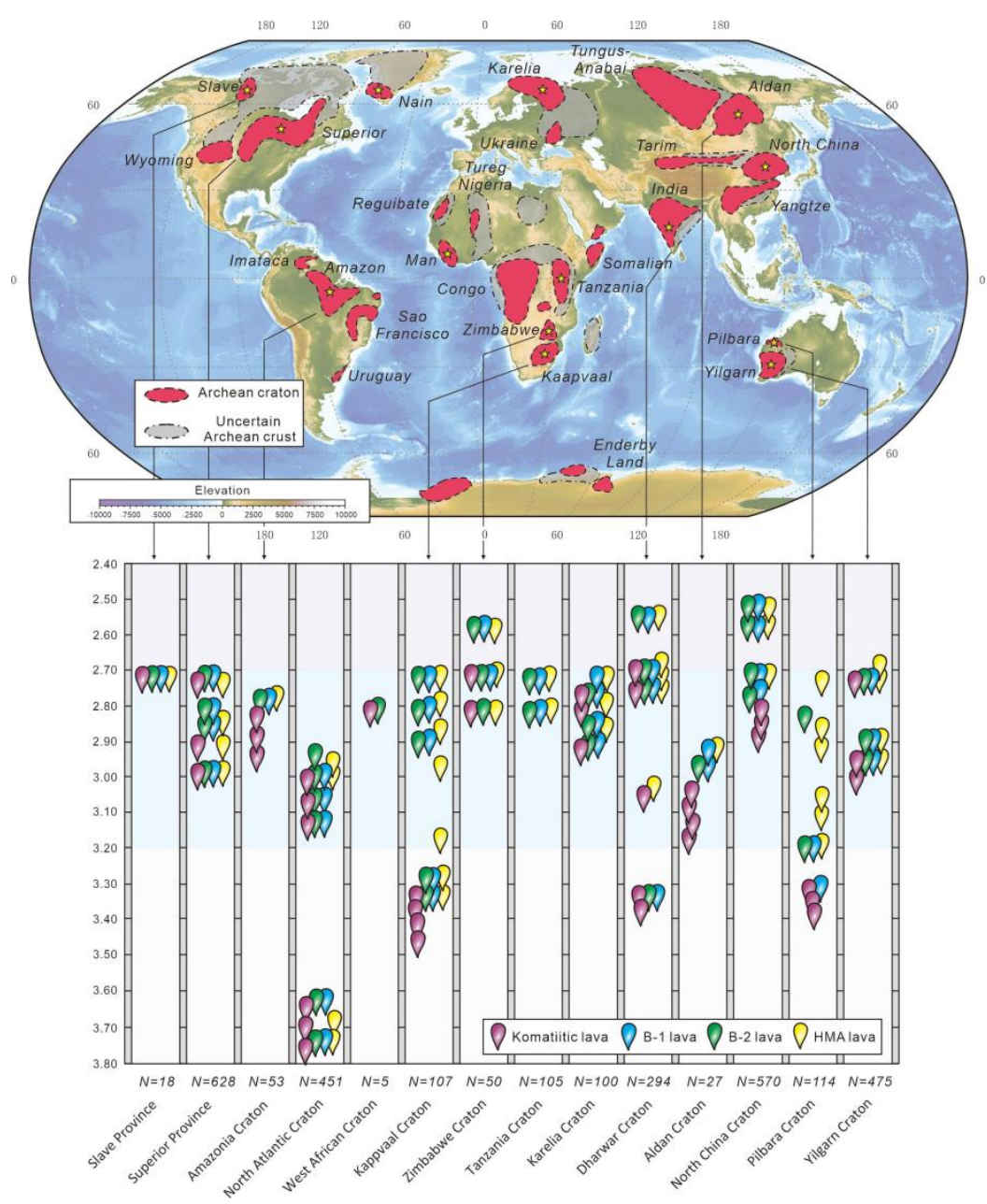

Figure 1 Spatial and temporal distribution of global mantle-derived volcanic rocks. Top, Map of exposed Archean cratons. According to statistics, at least fourteen cratons have Archean mantle-derived volcanic rock records. Bottom, Simplified age distribution of mantle-derived magmatism for each selected craton.

\section{Archean mantle-derived volcanic rocks}

The $3.8-2.5$ Ga mantle-derived volcanic rocks in the whole-rock geochemical database were classified as komatiites $(\mathrm{N}=551, \mathrm{MgO} \geq 18$ wt.\%), basalts $(\mathrm{N}=2133$, $\mathrm{MgO}<18$ wt. $\%)$ and HMAs $\left(\mathrm{N}=313, \mathrm{SiO}_{2}=54-65\right.$ wt. $\%, \mathrm{MgO} \geq 5$ wt. $\%$ and $\mathrm{Mg} \#$ $\geq 45$, calculated as an atomic ratio of $\left.100 \times \mathrm{Mg} /\left(\mathrm{Mg}+\mathrm{Fe}_{\text {total }}\right)\right)^{13-17}($ Supplementary 
A statistical analysis of modern basalts from established tectonic settings suggests that $(\mathrm{Nb} / \mathrm{La})_{\mathrm{PM}}<0.75\left(\mathrm{PM}\right.$, primitive mantle normalized $\left.{ }^{18}\right)$ is a powerful criteria identifying primitive melts that were generated in subduction-related settings (Supplementary Fig. 2), whereas the non-subduction basaltic melts have (Nb/La)PM $\geq$ 0.75. On this basis, Archean basalts are subdivided into B-1 and B-2 groups with $(\mathrm{Nb} / \mathrm{La})_{\mathrm{PM}} \geq$ and $<0.75$, respectively. The $\mathrm{B}-1$ samples $(\mathrm{N}=740)$ predominantly belong to the tholeiitic rock series according to their low $\mathrm{La} / \mathrm{Yb}$ ratios of $0.50-3.73$ $\left(\mathrm{La} / \mathrm{Yb} \leqslant 2.6\right.$ for tholeiitic and $\mathrm{La} / \mathrm{Yb} \geqslant 5.3$ for calc-alkaline rock series $\left.{ }^{19}\right)$ and have left-declined to nearly flat rare earth element (REE) patterns, similar to modern MORBs (Supplementary Fig. 3). Whereas the B-2 samples $(\mathrm{N}=1393)$ are intermediate between tholeiitic and calc-alkaline rock series with a wide range in $\mathrm{La} / \mathrm{Yb}$ ratios (up to 72 ), clearly distinct to $\mathrm{B}-1$ samples, and show flat to right-declined patterns, similar to basalts in modern arcs and back-arc basins (Supplementary Fig. 3). The HMAs are mainly attributed to calc-alkaline rock series based on their high $\mathrm{La} / \mathrm{Yb}$ ratios (up to 36 ), and have the lowest average (Nb/La)PM ratio of $0.35^{15}$ (Supplementary Fig. 3). Detailed descriptions of each rock type are listed in Methods.

\section{Redox state of Archean upper mantle}

The principle of the $\mathrm{V}-\mathrm{Ti}$ redox proxy is that $\mathrm{V}$ is a multivalent element $(2+, 3+, 4+$ and 5+), and its $\mathrm{Kds}$ vary with $\mathrm{fO}_{2}$, melting $\mathrm{P}-\mathrm{T}$ conditions and mineral compositions, in contrast with the $\mathrm{Kds}$ of $\mathrm{Ti}$ which are independent of $\mathrm{fO}_{2}{ }^{1,6,8}$. Based on a thorough 
consideration of peridotite melting reactions and water contents, this method has successfully estimated the $f \mathrm{O}_{2}$ of both modern ambient and arc (or modified) mantle ${ }^{8}$, providing a viable solution to the mantle $f \mathrm{O}_{2}$ debate in the early Earth.

Before determining $f \mathrm{O}_{2}$, it is necessary to calculate melting conditions for the parental magmas of the basalts. We use the Fractionated-PT software, and only samples with $\mathrm{MgO}>9$ wt.\% were used to avert possible effects from the late overprint of fractional crystallization and crust contamination ${ }^{20}\left(\right.$ Supplementary Table $^{2}$ 2; Supplementary Fig. 4). Due to the lack of water content assessment for Archean samples, we tentatively used the modern values of MORBs $(\sim 0.2 \mathrm{wt} . \%)$ and IABs ( 2-4 wt.\%) to represent those of Archean B-1 and B-2 samples, respectively ${ }^{16,21,22}$. The results indicate that B-1 samples were derived at high temperatures $(\mathrm{T}=$ $\left.\sim 1320-1658^{\circ} \mathrm{C}\right)$ and pressures $(\mathrm{P}=\sim 0.8-4.7 \mathrm{GPa})$, corresponding to the potential temperature (TP) of $\sim 1600{ }^{\circ} \mathrm{C}$ (Supplementary Fig. 4a), clearly distinct to that of komatiites $\left(\mathrm{T}_{\mathrm{P}}=\sim 1750-1950{ }^{\circ} \mathrm{C}\right)^{5}$. In contrast, B-2 samples exhibit significantly lower level conditions with $\mathrm{T}=\sim 1218-1583{ }^{\circ} \mathrm{C}$ and $\mathrm{P}=\sim 0.6-3.7 \mathrm{GPa}$ at 2 wt. $\% \mathrm{H}_{2} \mathrm{O}$ and $\mathrm{T}=\sim 1199-1519^{\circ} \mathrm{C}$ and $\mathrm{P}=\sim 0.7-3.4 \mathrm{GPa}$ at 4 wt. $\% \mathrm{H}_{2} \mathrm{O}^{20,22}$. The melting P-T conditions generally straddle the phase transition zone ( $\mathrm{P}=\sim 2.2 \mathrm{GPa}$ ) between spineland garnet-facies ${ }^{20,23}$. We therefore employ near fractional melting to perform both spinel (a) and garnet lherzolite (b) melting models for B-1 samples, and spinel lherzolite (c) melting for B-2 samples under hydrous conditions ${ }^{24-26}$ (Supplementary Table 3). Detailed parameter selections and calculation processes are listed in Methods. 
The mean Ti/V ratios of B-1 and B-2 samples are $18.9 \pm 0.4(1 \sigma)$ and $18.6 \pm 0.3$, respectively, significantly lower than those of the modern MORBs $(29 \pm 0.4)$ and IABs $(25 \pm 0.4)\left(\right.$ Supplementary Table 1; Supplementary Fig. 5) ${ }^{8}$. When converting V-Ti systematics to mantle $f \mathrm{O}_{2}$, the results of ambient mantle indicated by B-1 magmas basically remain constant with $\triangle \mathrm{FMQ}-1.18 \pm 0.12(1 \sigma)$ prior to $\sim 3.2 \mathrm{Ga}$, consistent with those obtained by $\mathrm{V}-\mathrm{Sc}$ redox proxy $(\triangle \mathrm{FMQ}-1.19 \pm 0.33)^{1,7}$, but they become increasingly heterogeneous between $\sim 3.2 \mathrm{Ga}$ to $2.7 \mathrm{Ga}$ (Fig. 2a; Supplementary Table 2). Subsequently, the ambient mantle has generally experienced a significant oxidation, as shown by a $\sim 0.5 \log$ unit increase from in $\triangle F M Q$ beneath the Dharwar Craton from $-1.24 \pm 0.09$ to $-0.66 \pm 0.06$ after $\sim 2.8 \mathrm{Ga}$ (Fig. 2a). There is also a significant $f \mathrm{O}_{2}$ difference between B-1 and B-2 samples, indicating the redox heterogeneity between ambient and modified mantle (Fig. 2). The mantle sources of B-2 samples have experienced a secular oxidization process over $\sim 3.8-2.5 \mathrm{Ga}^{3,4,27}$ (Fig. 2b,c). For example, the $f \mathrm{O}_{2}$ values of modified mantle beneath the Dharwar Craton exhibit a $\sim 1.5 \log$ unit increase from $\triangle \mathrm{FMQ}-1.75 \pm 0.31$ to $\triangle \mathrm{FMQ}-0.40 \pm$ 0.14 at 2 wt. $\% \mathrm{H}_{2} \mathrm{O}$ and $\triangle \mathrm{FMQ}-1.25 \pm 0.33$ to $\triangle \mathrm{FMQ}+0.02 \pm 0.16$ at 4 wt. $\% \mathrm{H}_{2} \mathrm{O}$ between $\sim 3.4 \mathrm{Ga}$ to $2.6 \mathrm{Ga}$, and those beneath the North Atlantic Craton have a $\sim 1.0$ $\log$ unit increase from $\triangle \mathrm{FMQ}-1.86 \pm 0.15$ to $\triangle \mathrm{FMQ}-0.90 \pm 0.11$ at $2 \mathrm{wt} . \% \mathrm{H}_{2} \mathrm{O}$ and $\Delta \mathrm{FMQ}-1.37 \pm 0.15$ to $\Delta \mathrm{FMQ}-0.67 \pm 0.06$ at 4 wt. $\% \mathrm{H}_{2} \mathrm{O}$ between $\sim 3.8 \mathrm{Ga}$ to $3.0 \mathrm{Ga}$ (Fig. 2b,c; Supplementary Table 2). Although some Archean samples (e.g., from the Slave Province and the Yilgarn Craton) may have achieved a redox state similar to modern mid-oceanic ridges and magmatic arcs, most of the estimations are lower than 
modern MORBs (FMQ $-0.03 \pm 0.38$ ) and IABs (FMQ $+0.42 \pm 0.63$ at 2 wt. $\% \mathrm{H}_{2} \mathrm{O}$

155 and FMQ $+0.82 \pm 0.62$ at 4 wt. $\left.\% \mathrm{H}_{2} \mathrm{O}\right)^{8}$ (Fig. 2a), indicating that the Archean upper

156 mantle was intrinsically more reducing than it is today. Statistically, the whole-rock

$157 \mathrm{Ti} / \mathrm{V}$ ratios have a negative logarithmic correlation with the calculated mantle $\mathrm{fO}_{2}$

158 values ${ }^{8,20}$, indicative of the validity of the calculation methodology (Supplementary

159 Fig. 5). Notably, the slopes of Archean and modern primitive basalts are significantly

160 different (Supplementary Fig. 5), reflecting the difference in mantle melting

161 conditions, which would directly influence the Kds of Ti and $\mathrm{V}^{8}$.
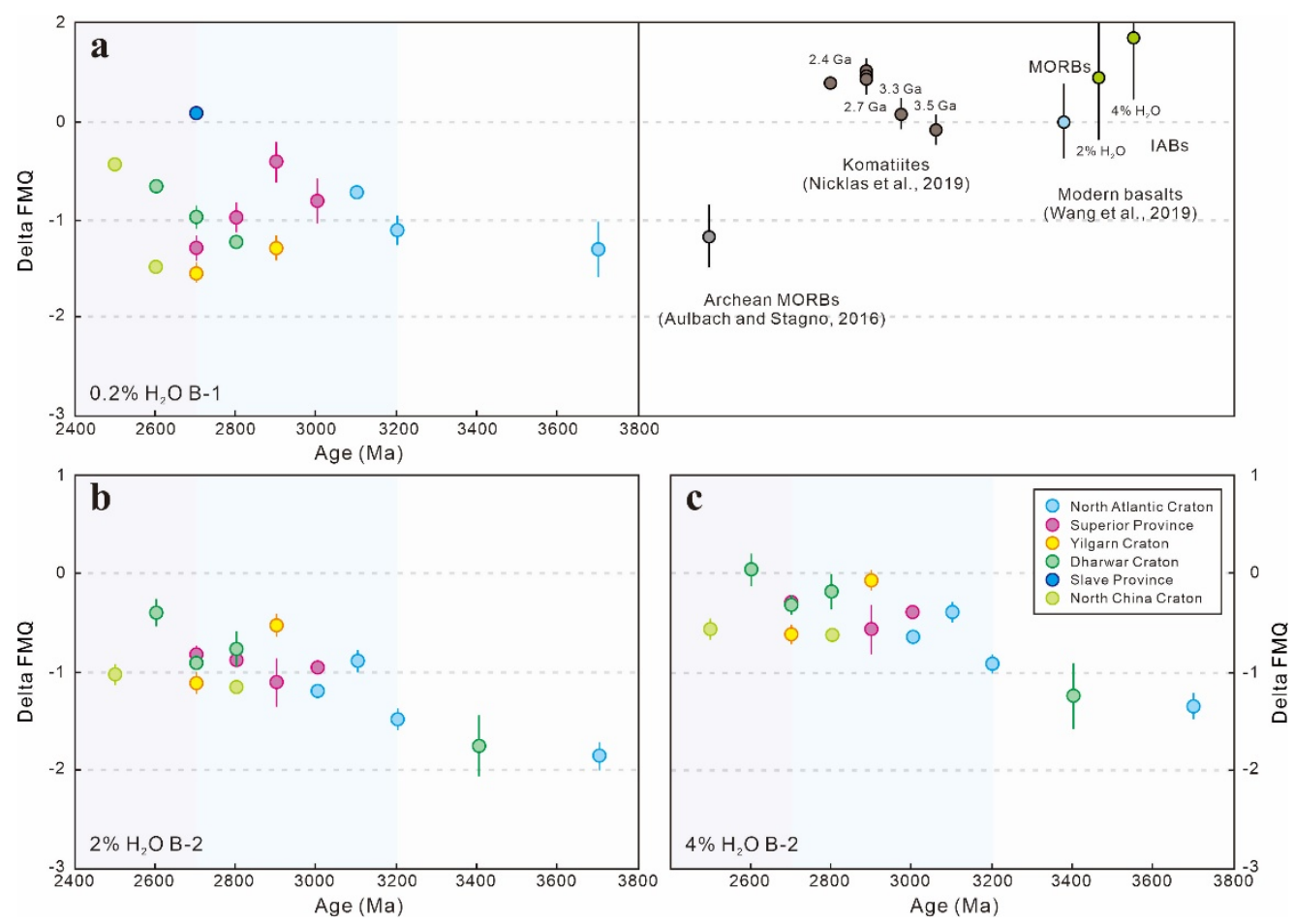

Figure 2 Redox state of Archean basalts calibrated by the updated V-Ti redox

proxy. a, The $f \mathrm{O}_{2}$ estimations for B-1 samples. The $f \mathrm{O}_{2}$ values of Archean

MORB-like samples estimated by previous V-Sc redox proxy, komatiites by the V partitioning and modern MORBs and IABs by V-Ti redox proxy were used for comparisons $^{3,7,8}$. bo, The $f \mathrm{O}_{2}$ estimations for B-2 samples at $2.0 \mathrm{wt} . \%$. c, The $f \mathrm{O}_{2}$ estimations for B-2 samples at $4.0 \mathrm{wt} . \%$. Error bars show the 1-standard errors of the means. 


\section{Increase in crustal recycling into the mantle}

Based on the statistics, the Archean volcanic rocks have a significant three-stage temporal and spatial distribution: (1) Prior to $\sim 3.2 \mathrm{Ga}$, the rock record is mainly characterized by tholeiitic chemical features (Supplementary Fig. 3b,c), represented by several ancient cratons (the Kaapvaal Craton, North Atlantic Craton, Dharwar Craton and Pilbara Craton) ${ }^{12,27,28}$ (Fig. 1), and the komatiites account for half of the global volcanic rock database (48 \%), whereas the B-2, HMA and possible calc-alkaline andesite samples, are mainly concentrated in the North Atlantic Craton, which also accounts for a quarter $(25 \%)$ of synchronous sample size of the database

171 (Fig. 3a), indicating that the non-subduction geodynamic regime play a dominant role during $\sim 3.8-3.2 \mathrm{Ga}^{17,27-29}$; (2) During $3.2-2.7 \mathrm{Ga}$, calc-alkaline magmatism is more widespread on a global scale s0,31 $^{3}$ (Supplementary Fig. 3d,e), and the proportions of B-2, HMA and andesite samples increase to $37 \%$, whereas komatiites decreased to $32 \%$ (Fig. 3b), consistent with the global development of plate subduction or other similar mechanisms ${ }^{30,32,33}$; and (3) Most of cratons experienced a long period of magmatic quiescence after $\sim 2.7 \mathrm{Ga}$, with only the North China, Zimbabwe and Dharwar cratons displaying significant $\sim 2.7-2.5$ Ga magmatism ${ }^{34,35}$ (Fig. 1). Komatiite components are essentially absent from these younger cratons and were replaced by the dominant calc-alkaline compositions (82\%) (Fig. 3c).

181 Geochemical modelling indicates that the compositional diversity of Archean 182 basalts was most likely related to the introduction of oceanic crust- and sediment-derived melts with high $\mathrm{fO}_{2}$, which are features related to the recycling of 
crustal materials into the mantle on the modern Earth ${ }^{12,17,36}$ (Fig. 3d-f; Supplementary

Fig. 6). The proportion of recycling increased significantly after $\sim 3.2 \mathrm{Ga}$ (Fig. 3d-f; mantle via plate subduction could be the most powerful mechanism leading to secular oxidization of Archean mantle.

a

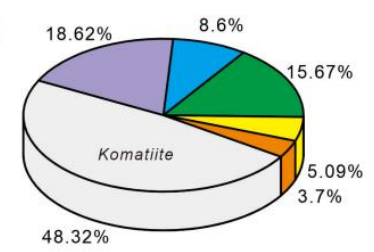

3. 8-3. $2 \mathrm{Ga}$

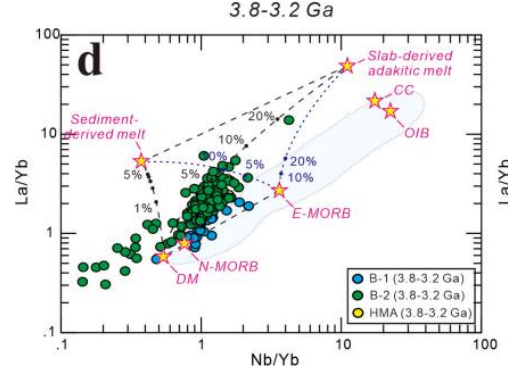

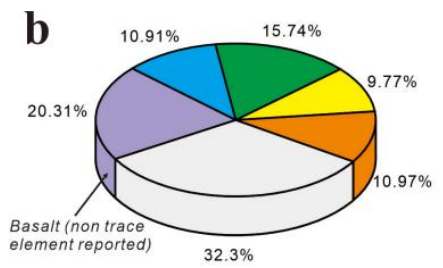

3. $2-2.7 \mathrm{Ga}$

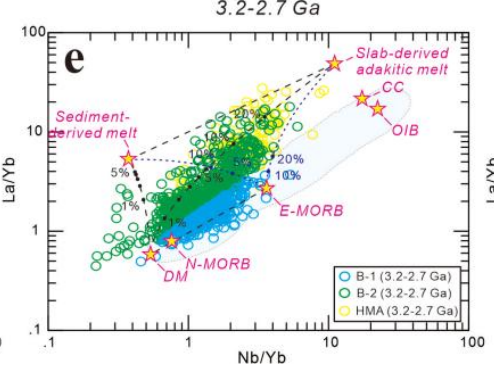

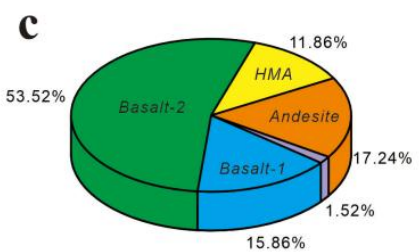

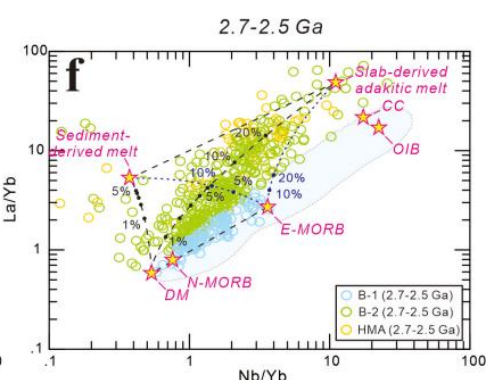

Figure 3 2D-Pie chart of lithological proportions (a-c) and $\mathrm{La} / \mathrm{Yb}$ versus $\mathrm{Nb} / \mathrm{Yb}$

diagram of crustal recycling (d-e) for $\sim 3.8-3.2 \mathrm{Ga}, \sim 3.2-2.7 \mathrm{Ga}$ and $\sim 2.7-2.5 \mathrm{Ga}$ volcanic samples, respectively. The values of $\mathrm{N}$ (norm)- and $\mathrm{E}$ (enriched)-MORB and oceanic island basalt (OIB) are from Sun and McDonough ${ }^{18}$. The shaded area was outlined by modern samples collected from mid-oceanic ridges, oceanic islands and 
oceanic plateaus, of which parental magmas were not metasomatized by slab-derived

fluids or melts and carbonatitic melts (data from the GEOROC database). The chemical tendencies were calculated using a series of binary mixing modelling between DM and possible metasomatic agents (oceanic crust- and sediment-derived melts), respectively (see Methods for details).

\section{References}

1. Aulbach, S. et al. Evidence for a dominantly reducing Archaean ambient mantle crust. Sci. Rep. 9, 20190 (2019).

2. Frost, D. J. \& McCammon, C. A. The Redox State of Earths Mantle. Annu. Rev. Earth Planet. Sci. 36, 389-420, 124322 (2008).

3. Nicklas, R. W. et al. Secular mantle oxidation across the Archean-Proterozoic boundary: Evidence from $\mathrm{V}$ partitioning in komatiites and picrites. Geochim. Acta 222, 447-466 (2018).

5. Sossi, P. A. et al. Petrogenesis and Geochemistry of Archean Komatiites. J. Petrol. Cosmochim. Acta 250, 49-75 (2019).

4. Nicklas, R. W., Puchtel, I. S. \& Ash, R. D. Redox state of the Archean mantle Evidence from V partitioning in 3.5-2.4 Ga komatiites. Geochim. Cosmochim. (2004). 
7. Aulbach, S. \& Stagno, V. Evidence for a reducing Archean ambient mantle and its effects on the carbon cycle. Geology 44, 751-754 (2016).

8. Wang, J. et al. Oxidation State of Arc Mantle Revealed by Partitioning of V, Sc, and Ti Between Mantle Minerals and Basaltic Melts. J. Geophys. Res. Solid Earth 124, 4617-4638 (2019).

9. Dauphas, N. et al. Iron isotopes may reveal the redox conditions of mantle melting from Archean to Present. Earth Planet. Sci. Lett 288, 255-267 (2009).

10. Stolper, D. A. \& Bucholz, C. E. Neoproterozoic to early Phanerozoic rise in island arc redox state due to deep ocean oxygenation and increased marine sulfate levels. Proc. Natl. Acad. Sci. 116, 8746-8755 (2019).

11. Gao, L. et al. A Ca. 2.8-Ga Plume-Induced Intraoceanic Arc System in the Eastern North China Craton. Tectonics 38, 1694-1717 (2019).

12. Polat, A. Geochemical variations in Archean volcanic rocks, southwestern Greenland: Traces of diverse tectonic settings in the early Earth. Geology 41, 379-380 (2013).

13. Chen, K. et al. How mafic was the Archean upper continental crust? Insights from $\mathrm{Cu}$ and $\mathrm{Ag}$ in ancient glacial diamictites. Geochim. Cosmochim. Acta 278, 16-29 (2019).

14. Arndt, N.T. Komatiites, kimberlites, and boninites. J. Geophys. Res. Solid Earth 108, B6 (2003). 
15. Kelemen, P. B., Yogodzinski, G. M. \& Scholl, D. W. Along-Strike Variation in the Aleutian Island Arc: Genesis of High Mg\# Andesite and Implications for Continental Crust. (American Geophysical Union (AGU), 2013).

16. Wood, B. J. \& Turner, S. P. Origin of primitive high-Mg andesite: Constraints from natural examples and experiments. Earth Planet. Sci. Lett. 283, 59-66 (2009).

17. Szilas, K. A Geochemical Overview of Mid-Archaean Metavolcanic Rocks from Southwest Greenland. Geosciences 8, 266 (2018).

18. Sun, S. S. \& McDonough, W. F. in Magmatism in the Ocean Basins (eds Saunders, A. D. \& Norry, M. J.) 313-345 (Geological Society, 1989).

19. Ross, P. S. \& Bédard, J. H. Magmatic affinity of modern and ancient subalkaline volcanic rocks determined from trace-element discriminant diagrams. Can. J. Earth. Sci. 46, 823-839 (2009).

20. Lee, C.-T. A., Luffi, P., Plank, T., Dalton, H. \& Leeman, W. P. Constraints on the depths and temperatures of basaltic magma generation on Earth and other terrestrial planets using new thermobarometers for mafic magmas. Earth Planet. Sci. Lett. 279, 20-33 (2009).

21. Plank, T., Kelley, K. A., Zimmer, M. M., Hauri, E. H. \& Wallace, P. J. Why do mafic arc magmas contain $\sim 4 \mathrm{wt} \%$ water on average? Earth Planet. Sci. Lett. 364, 168-179 (2013). 
22. Li, W., Jin, Z., Li, H. \& Tao, C. High water content in primitive mid-ocean ridge basalt from Southwest Indian Ridge $\left(51.56^{\circ} \mathrm{E}\right)$ : Implications for recycled hydrous component in the mantle. J. Earth. Sci. 28, 411-421 (2017).

23. ONeill, H.S.C. The transition between spinel lherzolite and garnet lherzolite, and its use as a geobarometry. Contrib. Mineral. Petrol. 77, 185-194 (1981).

24. Walter, M. J. Melting of Garnet Peridotite and the Origin of Komatiite and Depleted Lithosphere. J. Petrol. 39, 29-60 (1998).

25. Falloon, T. J., Green, D. H., Danyushevsky, L. V., \& McNeill, A. W. The composition of near-solidus partial melts of fertile peridotite at 1 and $1.5 \mathrm{GPa}$ : Implications for the petrogenesis of MORB. J. Petrol. 49, 591-613 (2008).

26. Gaetani, G. A. \& Grove, T. L. The influence of water on melting of mantle peridotite. Contrib. Mineral. Petrol. 131, 323-346 (1998).

27. Polat, A., Appel, P. W. U. \& Fryer, B. J. An overview of the geochemistry of Eoarchean to Mesoarchean ultramafic to mafic volcanic rocks, SW Greenland: Implications for mantle depletion and petrogenetic processes at subduction zones in the early Earth. Gondwana Res. 20, 255-283 (2011).

28. Nebel, O., Campbell, I. H., Sossi, P. A. \& Van Kranendonk, M. J. Hafnium and iron isotopes in early Archean komatiites record a plume-driven convection cycle in the Hadean Earth. Earth Planet. Sci. Lett. 397, 111-120 (2014).

29. Wang, C. et al. Palaeoarchaean deep mantle heterogeneity recorded by enriched plume remnants. Nat. Geosci. 12, 672-678 (2019). 
30. Cawood, P. A. et al. Geological archive of the onset of plate tectonics. Phil. Trans. R. Soc. A 376, 20170405 (2018).

31. Moyen, J. F. \& Laurent, O. Archaean tectonic systems: A view from igneous rocks. Lithos 302-303, 99-125 (2018).

32. Hawkesworth, C., Cawood, P. A. \& Dhuime, B. Rates of generation and growth of the continental crust. Geosci. Front. 10, 165-173 (2019).

33. Dhuime, B., Wuestefeld, A. \& Hawkesworth, C. J. Emergence of modern continental crust about 3 billion years ago. Nat. Geosci. 8, 552-555 (2015).

34. Wang, W. et al. Neoarchean intra-oceanic arc system in the Western Liaoning Province: Implications for Early Precambrian crustal evolution in the Eastern Block of the North China Craton. Earth Sci. Rev. 150, 329-364 (2015).

35. Krapež, B. et al. Tectonostratigraphy of the Late Archean Dharwar Supergroup, Dharwar Craton, India: Defining a tectonic history from spatially linked but temporally distinct intracontinental and arc-related basins. Earth Sci. Rev. 201, 102966 (2020).

36. Lara, M. \& Dasgupta, R. Partial melting of a depleted peridotite metasomatized by a MORB-derived hydrous silicate melt-Implications for subduction zone magmatism. Geochim. Cosmochim. Acta 290, 137-161 (2020).

37. Hawkesworth, C. \& Kemp, T. A Pilbara perspective on the generation of Archaean continental crust. Chem. Geol. 578, 120326 (2021).

38. Klein, B. Z., Jagoutz, O. \& Behn, M. D. Archean crustal compositions promote full mantle convection. Earth Planet. Sci. Lett. 474, 516-526 (2017). 
39. Capitanio, F. A., Nebel, O., Cawood, P. A., Weinberg, R. F. \& Clos, F. Lithosphere differentiation in the early Earth controls Archean tectonics. Earth Planet. Sci. Lett. 525 (2019).

40. van Hunen, J. \& van den Berg, A. P. Plate tectonics on the early Earth: Limitations imposed by strength and buoyancy of subducted lithosphere. Lithos 103, 217-235 (2008).

Correspondence and requests for materials should be addressed to Shuwen Liu (swliu@pku.edu.cn).

\section{Acknowledgements}

We sincerely wish to thank C.J. Hawkesworth for constructive suggestions to this contribution. We also want to thank C. Wang and X.S. Li with R language technology. This study was financially supported by the National Natural Science Foundation of China (Grant Numbers: 41530207, 41772188) and Peter A. Cawood acknowledges support from Australian Research Council grant FL160100168.

\section{Author contributions}

L. Gao, S.W. Liu and P.A. Cawood conceived and designed the project. L. Gao and S.W. Liu wrote the manuscript. J.T. Wang helped to calculate the oxygen fugacity. G.Z. Sun, Y.L. Hu and F.Y. Hu built the geochemical database and performed data processing. All the authors contributed to the interpretation of the results and the revision of this manuscript. 


\section{Competing interests}

The authors declare no competing interests.

\section{Additional information}

Supplementary information is available in the online version of the paper.

\section{Methods}

Data collection and filtration. In this study, the whole-rock geochemical database of

3.8-2.5 Ga volcanic rocks is a combination of the GEOROC database

volcanic database assembled by our research group. The principles for data filtration are as follows: (1) For accurate estimation of mantle redox state, the samples must be directly produced by melting of mantle peridotite, namely, mantle-derived, so that their $\mathrm{SiO}_{2}$ content should be in the range of typical basalt and basaltic andesite composition (45-54 wt.\%) based on experimental petrology ${ }^{20}$. In addition, there are a number of locations where primitive magmas are inferred to be $\mathrm{HMAs}\left(\mathrm{SiO}_{2}=54-65\right.$ wt. $\%, \mathrm{MgO} \geq 5$ wt. $\%$ and $\mathrm{Mg \#} \geq 45)^{15,16}$, therefore, samples satisfied with HMA criteria are also retained; (2) They should have reliable formation ages traced by isotopic dating methods (mainly via whole-rock Sm-Nd, Re-Os and magmatic zircon $\mathrm{U}-\mathrm{Pb}$ isotopic systematics) or limited by geological relationships. Subsequently, data statistics was conducted to these samples based on their rock types, and temporal and 

with matched major and trace element data (best to contain the information of $\mathrm{V}, \mathrm{Ti}$, La and $\mathrm{Nb}$ ) are preserved; (4) The least-altered Archean volcanic rocks are reported to have low loss on ignition (LOI, $<6$ wt. $\%)$ and negligible $\mathrm{Ce}$ anomalies $\left(0.9<\mathrm{Ce} / \mathrm{Ce}^{*}\right.$ $<1.1$, calculated as $\left.\operatorname{Ce}_{\mathrm{N}} / \operatorname{Sqrt}\left(\operatorname{Lan}_{\mathrm{N}} \times \operatorname{Pr}_{\mathrm{N}}\right)\right)^{41}$, therefore, the collected basalts and HMAs not satisfied with these criteria are filtrated. Due to their commonly high LOI contents, negligible Ce anomalies is tentatively considered to be the only criterion for komatiites; and (5) Samples affected by significant crustal contamination discussed in the original literatures are also filtrated. After data filtration, this database comprises a total of 2997 samples that cover fourteen ancient cratons (Fig. 1; Supplementary Table 1).

Geochemical characteristics of mantle-derived volcanic rocks. The komatiites were subdivided into Al-depleted (ADKs, $\mathrm{N}=90$ ) and Al-undepleted komatiites (AUKs, $\mathrm{N}=461$ ) based on $\mathrm{Al}_{2} \mathrm{O}_{3} / \mathrm{TiO}_{2}<$ and $\geq 15.0$, respectively ${ }^{5,14}$. The ADKs exhibit low $\mathrm{Al}_{2} \mathrm{O}_{3} / \mathrm{TiO}_{2}$ ratios $\left(1.76-14.9\right.$, average 11.0) and average $(\mathrm{Gd} / \mathrm{Yb})_{\mathrm{N}}$ ratio of 1.50 with nearly flat REE patterns. The AUKs have significantly higher $\mathrm{Al}_{2} \mathrm{O}_{3} / \mathrm{TiO}_{2}$ ratios $(15.0-40$, average 22$)$ but lower average $(\mathrm{Gd} / \mathrm{Yb})_{\mathrm{N}}$ ratio of 1.05 , and their $\mathrm{REE}$ patterns are more depleted in light rare earth elements (LREEs) ${ }^{5,14}$ (Supplementary 354 Table 1).

B-1 samples $(\mathrm{N}=740)$ predominantly belong to the tholeiitic rock series 356 (Supplementary Fig. 3b,d,f). They are characterized by low $\mathrm{SiO}_{2}$ contents 357 (45.11-53.91 wt.\%, average 50.00 wt.\%), variable $\mathrm{MgO}$ (3.98-17.50 wt.\%, average 
8.43 wt.\%) and $\mathrm{TFeO}(6.13-17.51$ wt.\%, average 12.01 wt.\%) contents and other

359

360

361

362

363

364

365

366

367

368

369

370

371

372

373

374

375

376

377

378

379

transition metals, for example V contents (102-660 ppm, average $299 \mathrm{ppm})$, and Mg\#

values (40-78, average 58) (Supplementary Table 1). They have LREE depleted to nearly flat REE patterns with an average $(\mathrm{La} / \mathrm{Yb})_{\mathrm{N}}$ ratio of 1.05 , and negligible $\mathrm{Nb}$ and Ta anomalies with an average ( $\mathrm{Nb} / \mathrm{La}$ )PM ratio of 0.91 (Supplementary Table 1).

B-2 samples $(\mathrm{N}=1393)$ have similar major oxide features to those of B-1 with $\mathrm{SiO}_{2}$ (45.00-53.99 wt.\%, average 50.55 wt.\%), $\mathrm{MgO}$ (2.55-17.61 wt.\%, average 8.43 wt.\%) and $\mathrm{TFeO}(5.86-18.11$ wt.\%, average 11.18 wt.\%) contents and $\mathrm{Mg} \#$ values (39-83, average 60). Their $\mathrm{V}$ contents (36-586 ppm, average $258 \mathrm{ppm}$ ) are slightly lower than those of the B-1 samples (Supplementary Table 1), and in terms of REE ratios they are intermediate between tholeiitic and calc-alkaline rock series, clearly distinct to B-1 samples (Supplementary Fig. 3c,e,g). Most B-2 samples have flat to LREE enriched patterns with an average $(\mathrm{La} / \mathrm{Yb})_{\mathrm{N}}$ ratio of 2.79 , and they have negative $\mathrm{Nb}$ and $\mathrm{Ta}$ anomalies with a low average $(\mathrm{Nb} / \mathrm{La}) \mathrm{PM}$ ratio of 0.50 (Supplementary Table 1).

The HMA samples are mainly attributed to calc-alkaline rock series (Supplementary Fig. 3c,e,g), and they have the highest $\mathrm{SiO}_{2}$ contents (54.00-64.20 wt.\%, average 56.13 wt.\%) and the lowest $\mathrm{MgO}$ (4.50-14.40 wt.\%, average 7.08 wt.\%), TFeO (4.49-13.52 wt.\%, average 8.61 wt.\%) and V (50-370 ppm, average 189 ppm) compared to Archean basalts (Supplementary Table 1). Their Mg\# values (47-78, average 62) are similar to those of the basalts, but they have fractionated REE patterns with an average $(\mathrm{La} / \mathrm{Yb})_{\mathrm{N}}$ ratio of 5.85 , and marked relative depletions in $\mathrm{Nb}$ and $\mathrm{Ta}$ 
with the $(\mathrm{Nb} / \mathrm{La})$ PM of 0.35 (Supplementary Table 1$)$.

381 Estimation of mantle $\mathbf{f O}_{\mathbf{2}}$ by $\mathrm{V}$-Ti redox proxy. $\mathrm{V}$ is a redox-sensitive element with variable valence states, whereas $\mathrm{Ti}$ is $\operatorname{not}^{1,3,4,6}$. In addition, both of them are generally considered to be immobile during dehydration and melting of oceanic crust (including sediments), and are not strongly enriched in continental crust $^{8}$. Together with their highly incompatible features among most mantle minerals, the V-Ti systematics can 'see through' early magmatic differentiation and be used as a stable $\mathrm{fO}_{2}$ discrimination.

In the mantle $f \mathrm{O}_{2}$ modelling, the content of trace element $i$ in the instantaneous melt is calculated by $C_{i, m}^{n+1}=\frac{C_{i, r}^{n}}{D_{i, b u l k}^{n+1}+F\left(1-D_{i, b u l k}^{n+1}\right)}$, where $C_{i, m}^{n+1}$ is the element content in the melt at step $n+1, C_{i, r}^{n}$ is the element content in the residue after melt extraction at step $n, D_{i, b u l k}^{n+1}$ is the bulk partition coefficient at step $n+1$, and $F$ is the melt fraction of each step ${ }^{8}$. Element $i$ content in the aggregated melt at step $\mathrm{j}$ is calculated by $C_{i}^{a g g r}=\frac{\sum_{I}^{j} C_{i, m}^{j} M_{m e l t}^{j}}{\sum M_{m e l t}^{j}}$, where $C_{i}^{a g g r}$ and $\sum M_{m e l t}^{j}$ are element $i$ content in the aggregated melt and bulk mass at step $j$, respectively, $C_{i, m}^{j}$ and $M_{m e l t}^{j}$ are the element $i$ content in the melt and mass at step $j$, respectively ${ }^{8}$. According to the DM compositions, the initial V and Ti contents are assumed to be 79 ppm and 798 ppm, respectively ${ }^{42}$.

The mineral assemblages of garnet lherzolite (model b) constitute by $52.3 \%$ olivine (Ol), 17.4\% orthopyroxene (Opx), 26.2\% clinopyroxene (Cpx) and 4.1\% garnet (Grt)

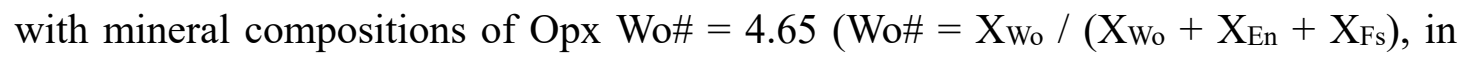
which $\mathrm{X}_{\mathrm{W}}, \mathrm{X}_{\mathrm{En}}$ and $\mathrm{X}_{\mathrm{Fs}}$ are fractions of Wollastonite, Enstatite and Ferrosilite, respectively), $\mathrm{Cpx} \mathrm{Al}^{\mathrm{T}}=0.21\left(\mathrm{Al}\right.$ in the tetrahedron-coordinated site), $\mathrm{Opx} \mathrm{Al}^{\mathrm{T}}=$ 
$0.19^{24}$. The melting reactions of dry garnet lherzolite at $\sim 3.0 \mathrm{GPa}$ were used for this model ${ }^{24}$. The melt productivity of $0.23 /{ }^{\circ} \mathrm{C}$ for lherzolite and $0.14 /{ }^{\circ} \mathrm{C}$ for harzburgite were used to calculated the melting degrees and temperatures ${ }^{25}$. The $\mathrm{Kds}$ of $\mathrm{V}$ in $\mathrm{Ol}$, Opx and Cpx, and Ti in Opx and Cpx at each melt fraction were calculated by recent empirical equations with variables of mineral compositions and melting P-T conditions ${ }^{7}$. In addition, the $\mathrm{Kds}$ of $\mathrm{V}$ in $\mathrm{Grt}$ and $\mathrm{Ti}$ in $\mathrm{Ol}$ and $\mathrm{Grt}$ are assumed to be constants and collected from http://earthref.org/GERM/.

The spinel lherzolite (models a and c) are composed of 57\% O1, 28\% Opx, 13\% Cpx and $2 \%$ Sp with Opx Wo\# $=4.38, \mathrm{Cpx} \mathrm{Al}^{\mathrm{T}}=0.17, \mathrm{Opx} \mathrm{Al}^{\mathrm{T}}=0.15$ and $\mathrm{Sp} \mathrm{Cr} \#=$ $10.65\left(\mathrm{Cr} \#=\mathrm{Cr}_{2} \mathrm{O}_{3} /\left(\mathrm{Cr}_{2} \mathrm{O}_{3}+\mathrm{Al}_{2} \mathrm{O}_{3}\right)\right.$ on a molar basis. $)$. However, the melting reactions for models a and c are significantly different: the former performed by dry peridotite at $1.5 \mathrm{GPa}$ and the latter by hydrous peridotite at 1.2-2.0 GPa, respectively ${ }^{25,26}$. The above-mentioned empirical equations were used to calculate the Kds of $\mathrm{V}$ in Ol, Opx, Cpx and Sp, and Ti in Opx and Cpx at each melt fraction ${ }^{7}$. During the calculations, the $f \mathrm{O}_{2}$ values varied from FMQ -4 to FMQ +4 at a step of $0.001 \log$ unit until the modelled $\mathrm{V}$ and Ti contents may match those of samples with the difference less than 5\%. All of the calculations are compiled into a macro document and listed in Supplementary Table 3.

Geochemical modelling for crust recycling. $\mathrm{Nb}$ (and $\mathrm{Ta}$ ) and REEs are generally considered to be incompatible during the partial melting of mantle peridotite but sensitive to subduction-related metasomatism ${ }^{43}$. Therefore, we perform a series of binary mixing calculations between the possible mantle sources and metasomatic 
agents of oceanic crust- and sediment-derived melts, respectively ${ }^{42,43}$ (Fig. 3d-f; Supplementary Fig. 6). The results indicate that the compositional diversity of Archean basalts is most likely related to recycling of oceanic crust materials, rather than the significant crustal contamination. The chemical compositions of oceanic crust-derived melts can be represented by those of average Archean tonalite-trondhjemite-granodiorite $(\mathrm{TTG})^{44}$. The compositions of sediment-derived melts are calculated using batch melting of a $\sim 2.7$ Ga metapelite sample from the Yangtze Craton, China, with the fraction (F) of melt ranging from 0.1 to $0.3^{45}$. The Kds are collected from http://earthref.org/GERM/.

\section{Data availability}

The authors declare that all data supporting the discoveries of this contribution are available within the article and its Supplementary Information files.

\section{References}

41. Polat, A. \& Hofmann, A. W. Alteration and geochemical patterns in the $3.7-3.8 \mathrm{Ga}$ Isua greenstone belt, West Greenland. Precambrian Res. 126, 197-218 (2003).

42. Workman, R. K. \& Hart, S. R. Major and trace element composition of the depleted MORB mantle (DMM). Earth Planet. Sci. Lett. 231, 53-72 (2005).

43. Laurent, O., Martin, H., Doucelance, R., Moyen, J.-F. \& Paquette, J.-L. Geochemistry and petrogenesis of high-K "sanukitoids" from the Bulai pluton, 
443 Central Limpopo Belt, South Africa: Implications for geodynamic changes at the $444 \quad$ Archaean-Proterozoic boundary. Lithos 123, 73-91 (2011).

445 44. Martin, H., Smithies, R. H., Rapp, R., Moyen, J. F. \& Champion, D. An overview 446 of adakite, tonalite-trondhjemite-granodiorite (TTG), and sanukitoid: relationships 447 and some implications for crustal evolution. Lithos 79, 1-24 (2005).

448 45. Wang, K., Dong, S., Li, Z.-X. \& Han, B. Age and chemical composition of 449 Archean metapelites in the Zhongxiang Complex and implications for early 450 crustal evolution of the Yangtze Craton. Lithos 320-321, 280-301 (2018). 


\section{Supplementary Files}

This is a list of supplementary files associated with this preprint. Click to download.

- SupplementaryTable2.xlsx

- SupplementaryInformation.pdf

- SupplementaryTable3.xlsx

- SupplementaryTable1.xlsx 